\title{
Tuberous sclerosis - A case report and review of literature
}

\section{Tüberoz skleroz bir vaka ve literatürün gözden geçirilmesi}

\section{Hari Krishan Aggarwal, Deepak Jain*, Promil Jain, Vipin Kaverappa, Ashwani Kumar, Sachin Yadav}

Department of Medicine (Prof. H. K. Aggarwal, MD, Assist. Prof. D. Jain, MD, P. Jain, MD, V. Kaverappa, MD, A. Kumar, MD, S. Yadav, MD), Pt. B. D. Sharma Postgraduate Institute of Medical Sciences IN-124001 Rohtak

\begin{abstract}
Tuberous sclerosis complex (TSC) is a neurocutaneous syndrome characterized by involvement of multiple system including central nervous system, kidney, skin, heart, lungs, and eye. It is frequently associated with skin lesions (96\%); seizures (90\%) and mental retardation (70\%). Most common lesions associated with TSC are angiofibroma of face, ashleaf macules, shagreen patches, subependymal nodules, cortical tubers, mental retardation, and angiomyolipomas of kidney. The small benign tumours in the brain of affected individuals are the cause of neurological manifestations of the disorder. As prognosis depends on the involvement of brain, kidney and other vital organs; routine screening of a patient with tuberous sclerosis is required to determine the involvement of other organ systems. Combined skills of physician, radiologists and psychologist are required to manage a patient with TSC.
\end{abstract}

Keywords: Tuberous sclerosis, angiomyolipomas, shagreen patches, subependymal nodules, ashleaf macules, seizures

\section{Özet}

Tüberoz skleroz kompleksi santral sinir sistemi, böbrek, deri, kalp, akciğerler ve göz gibi çoklu sistem tutulumlu nörokutanöz bir sendromdur. Deri lezyonları(\%96), nöbetler(\%90) ve mental retardasyonla (\%70) ilişkilidir. En sık görülen lezyonlar yüzde anjiofibrom, ash-leaf makülleri, shagreen lekeleri, subependimal nodüller, kortikal tüberler, mental retardasyon ve böbrekte anjiomyolipomlardır. Hastalığın nörolojik bulgularının nedeni beyindeki küçük benign tümörlerdir. Prognoz beyin, böbrek ve diğer hayati organların tutulumuna bağlı olduğu için diğer sistemik organ tutulumları da rutin taranmalıdır. Tüberoz sklerozlu hastanın tedavisinde hastayı izleyen hekimin; radyolog ve psikiatristle de işbirliği içerisinde olması gerekmektedir.

Anahtar sözcükler: Tüberoz skleroz, anjiomyolipomlar, shagreen patchler, subependimal nodüller, ash-leaf maküller, nöbetler

Geliş tarihi/Received: December 13, 2011; Kabul tarihi/Accepted: February 10, 2012

\section{*Corresponding author:}

Dr. Deepak Jain, 2/8 FM, Medical Campus Pt. BD Sharma PGIMS Rohtak-IN-124001 (Haryana) E-mail: hariaggarwal@rediffmail.com

\section{Introduction}

Tuberous sclerosis, also known as Bourneville's disease, is a neurocutaneous disorder characterized by cutaneous lesions, seizure and mental retardation. It is characterized by development of benign tumours, such as neurofibroma and angiofibroma located at multiple sites in the body (skin, central nervous system, kidney, heart etc.). It is an autosomal dominant hereditary disorder, though $60-70 \%$ of all cases are the result of spontaneous mutations [1, 2]. Patients with tuberous sclerosis have mutations in either 
TSC-1 gene at chromosome 9q34 or the TSC-2 gene at chromosome 16p13. These genes encode hamartin and tuberin proteins respectively that modulate the GTPase activity of the other cellular signaling proteins [3]. The unpredictable distribution of the lesions results in a broad range of clinical phenotypes, with variable expression even in same family [4]. The disease affects $1 / 6000$ to $1 / 10000$ births, and diagnosis is established between 4-10 years of age or at puberty [5]. The cutaneous lesions include adenoma sebaceum (facial angiofibroma), ashleaf shaped hypopigmented macules (best seen under wood's lamp), shagreen patches, depigmented naevi, periungual fibromas (also known as Koenen's tumor), and forehead plaques. Central nervous system (CNS) involvement is variable, including learning difficulties, seizure disorders and tumors. Three brain tumors may be associated with Tuberous sclerosis complex (TSC): giant cell astrocytoma (grows and blocks the cerebrospinal fluid (CSF) flow leading to dilatation of ventricles causing headache and vomiting), cortical tubers and subependymal nodule (from wall of the ventricles). $60-80 \%$ of TSC patients have benign tumors of kidney called angiomyolipomas which frequently cause hematuria. Some patients may have autosomal dominant polycystic kidney disease. Patients may have rhabdomyoma of striated myocardial muscles. Eye lesions include astrocytichamartoma, coloboma, angiofibroma of eyelid, and papilloedema (related to hydrocephalus).

The most common oral manifestations of TSC are fibromas, gingival hyperplasia and enamel hypoplasia [6]. Other less frequent findings in oral cavity are high arched palate, bifid uvula, delayed dental eruption, cleft palate and the presence of diastemas [7].

\section{Case report}

We hereby report a thirteen-year old young male who was admitted with history of generalized tonic clonic seizures since neonatal period. Patient was started on an antiepileptic drug (records not available) but seizures were not controlled, therefore patient was shifted to indigenous medications by parents, but got no relief. Patient presented in the emergency department with intractable seizures inspite of combination of antiepileptic medications. On examination, the patient had skin lesions over face especially concentrated around nose. The patient was hyperactive and had high arched palate, with depressed nasal bridge and frontal bossing. Dental hygiene was poor with generalized chronic gingivitis and gum inflammation. Skin examination showed adenoma sebaceum (angiofibromas) concentrated around nose, one fibrous plaque on forehead. Shagreen patches were present in preauricular region and hypomelanotic patches were present on trunk and face, most prominent in wood lamp examination (ashleaf macules) (Figure 1, 2 and 3).

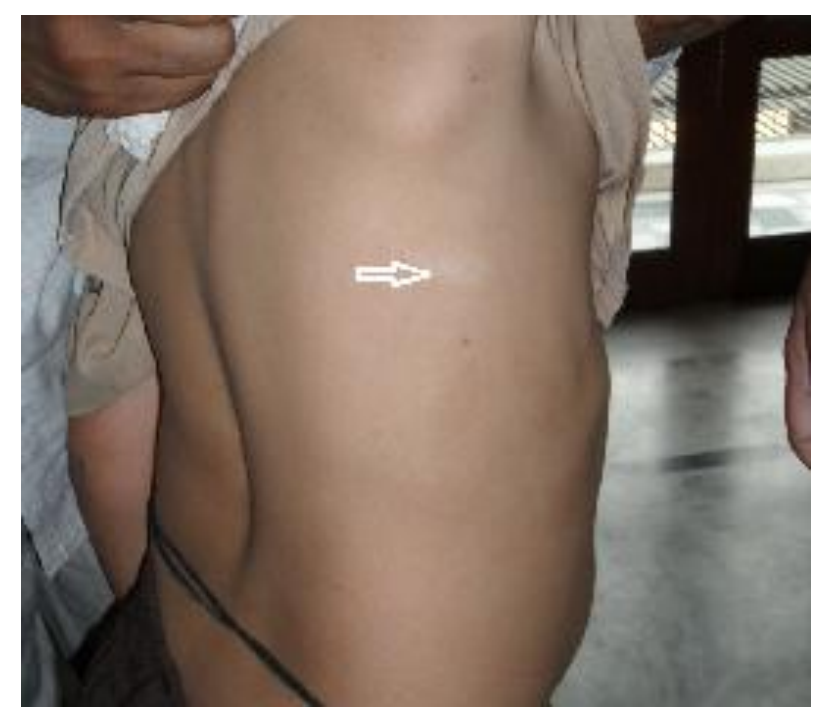

Figure 1. Photograph of patient showing shagreen patch. 


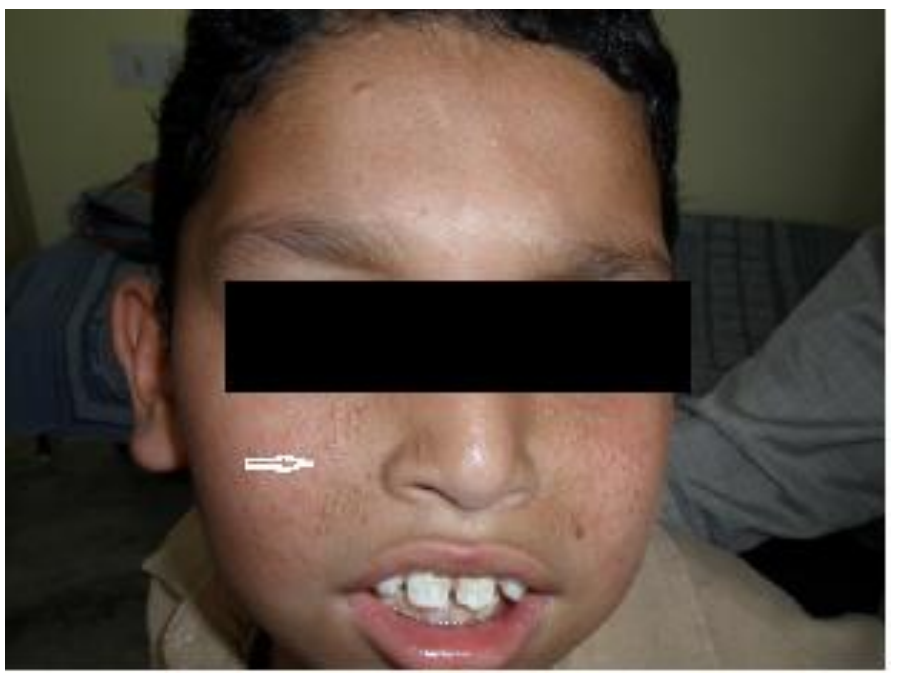

Figure 2. Photograph of the patient showing adenoma sebaceoum and gum hypertrophy.

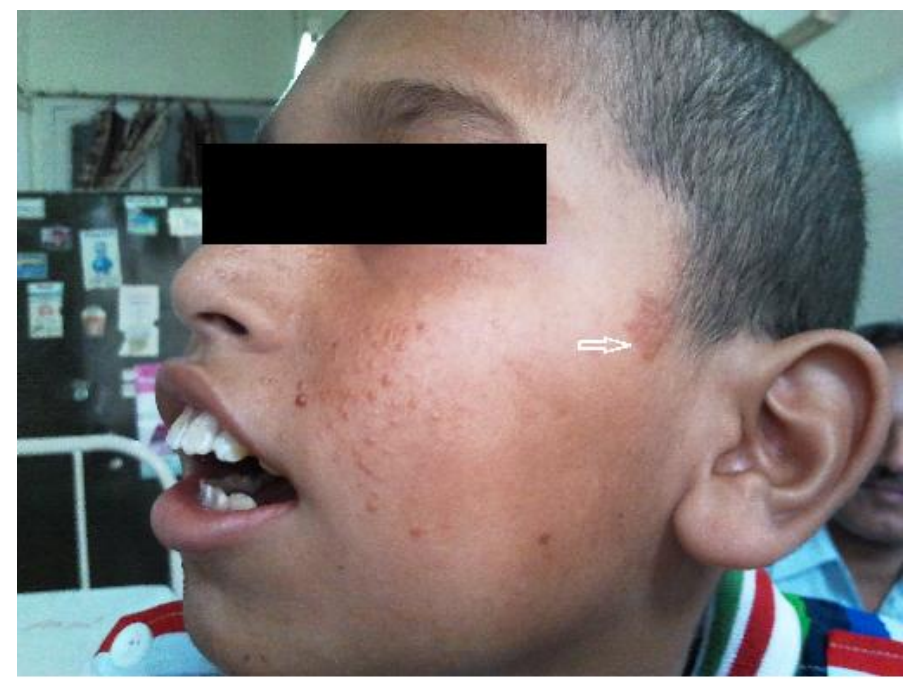

Figure 3. Photograph of patient showing ashleaf macules.

The intelligence quotient (IQ) of the patient was 30 indicating severe mental retardation with features suggestive of attention deficit and hyperactivity disorder (ADHD). Rest of systemic examination was normal. History of delayed gross motor, fine motor, language, perceptive cognitive, social and personal developmental milestones was present. There was no history of similar illness in any other sibling or family member. Subsequent investigations revealed normal hemogram including total leucocyte count, and platelet count, normal kidney and liver function tests, random blood sugar, serum electrolytes including calcium levels were within normal range. Urine complete examination shows no proteinuria, no hematuria. Chest radiography was normal. Ultrasonography of abdomen showed multiple echogenic lesions involving bilateral kidneys, the largest was $3.2 \times 2.5 \mathrm{cms}$ in size at midpole of left kidney suggestive of renal angiomyolipoma. Contrast enhanced computerized tomography (CECT) head shows calcified lesions in subependymal locations at bilateral lateral ventricles jetting into CSF, right cerebeller region and right occipital region suggestive of subependymal nodules, with nonenhancing, hypodense lesions seen scattered in the supratentorial brain parenchyma suggestive of cortical tubers (Figure 4). 


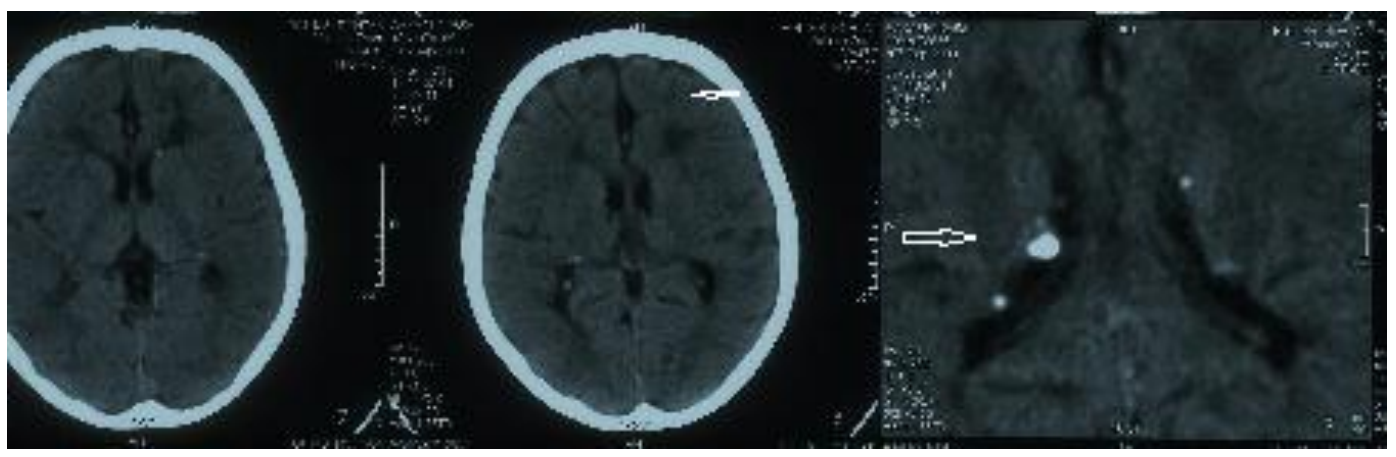

Figure 4. CECT brain showing subependymal nodule and cortical tubers.

CECT of the abdomen showed a hypodense lesion with areas of fat density seen in the left kidney, lesions showing heterogenous contrast enhancement confirming angiomyolipoma (Figure 5). Echocardiography was normal. Twenty three channel electroencephalography recordings under sedation showed a poorly organized background activity of bursts of generalized spike and wave discharged admixed with low and high voltage slow waveforms. Photostimulation was non contributory. Patient was treated with valproic acid and vigabatrin and is now controlled for seizures.

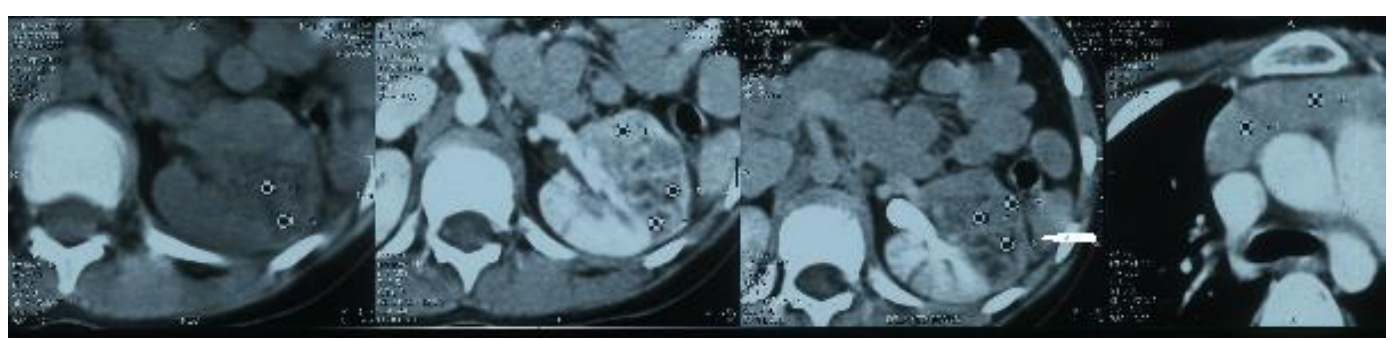

Figure 5. CECT abdomen showing angiomyolipoma.

\section{Discussion}

TSC is a neurocutaneous syndrome classically characterized by triad of skin lesions including facial angiofibromas (96\%), seizures (90\%) and mental retardation (70\%). The disease is a autosomal dominant genetic disorder with variable penetrance. Around two third of TSC cases result from sporadic genetic mutation, not inheritance, but their offspring inherit it from them. TSC 1 encodes hamartin located on chromosome 9q34. TSC 2 is contiguous with PKD1, the gene involved in polycystic kidney disease (PKD) on chromosome 16P13, it encodes for tuberin protein.

TSC 1 and 2 are both tumor suppression genes that function according to Knudson's "two hit" hypothesis. That is, a second random mutation must occur before a tumor can develops. This explains why despite its $100 \%$ penetrance, TSC has wide expressivity (Table 1).

Physical manifestations of tuberous sclerosis are due to formation of hamartia (malformed tissue such as cortical tubers), hamartoma (benign growth such as facial angiofibroma and subependymal nodules) and very rarely, cancerous hamartoblastoma. The effect of these on the brain leads to neurological symptoms such as seizures, developmental delay and behavioural problems [8]. 


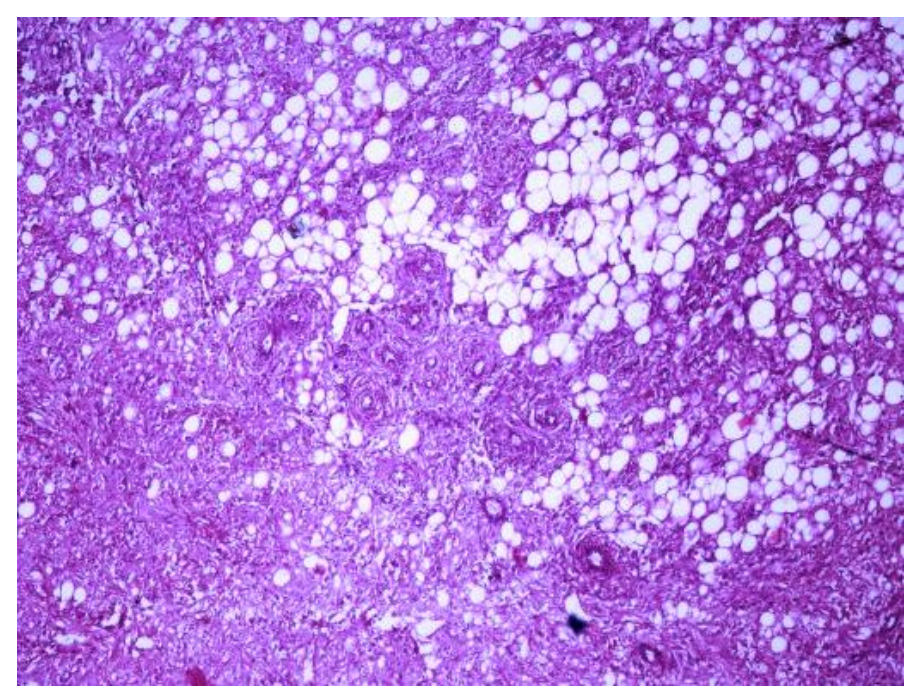

Figure 6. Photomicrograph of angiomyolipoma of kidney revealing adipose tissue, smooth muscle and vessels (H \& E 100X).

Up to $50 \%$ of children with tuberous sclerosis will develop rhabdomyoma of heart, which may cause congestive heart failure, conduction abnormalities, refractory arrhythmias, and severe hemodynamic compromise [13]. Cardiac rhabdomyomas are normally observed before age of 25 years in 30-50\% of all cases, and are also a cause for early death [14]. Our patient does not have any cardiac involvement. Drug therapy for some manifestations of TSC is currently in developmental stage [15]. Unless vital functions are affected, life expectancy is good. Majority of patients will require antiepileptics (Valproic acid, Vigabatrin, Topiramate) for control of seizure. Chiron et al. [16] and Aicardi et al. [17] reported efficacy of vigabatrin (VGB) in refractory infantile spasms and the best results in the patients of TSC. Of the patients affected by TSC 73 (95\%) had complete cessation of infantile spasms, in contrast to 169 (54\%) of patients without TSC. Topiramate is emerging as a more effective drug in partial seizures with or without secondary generalization and in Lennox-Gastaut syndrome [18]. Apart from state dependent blockade of sodium and calcium channels, the mechanism of action of Topiramate and inhibitory effect on carbonic anhydrase include enhanced GABA (Gamma aminobutyric acid) activity on GABAA receptors with elevated levels of cerebral GABA and antagonism of glutamate receptors. Everolimus was approved for treatment of SEGA in 2010. Behavioural therapy and educational strategies are required for mental retardation. Shunting for hydrocephalus may be required in some patients. Leading cause of death include renal disease, brain tumour, lymphangioleiomyomatosis of lung and status epilepticus or bronchopneumonia in those with severe mental retardation [19]. To conclude, patients of TSC can have variable presentations ranging from typical skin lesions, seizures and learning disabilities to atypical presentations like hematuria mimicking polycystic kidney disease, gum fibromas or rare CNS lesions. Hence, the diagnosis and management of patients with TSC require combined skills of a physician, radiologist and a psychologist. Seizure plays a major role in failure of mental development and deterioration of mental function, hence effective seizure control is needed. Though TSC is not a common diagnosis, it should be brought in mind when a young patient admits with complaints of resistant seizures with skin lesions and learning difficulties.

\section{References}

1. Inoki $\mathrm{K}, \mathrm{Guan} \mathrm{KL}$. Tuberous sclerosis complex, implication from a rare gnetic disease to common cancer treatment. Hum Mol Genet 2009; 18(R1): R94-100.

2. Hung CC, Su YN, Chien SC, Liou HH, Chen CC, Chen PC, Hsieh CJ, Chen CP, Lee WT, Lin WL, Lee CN. Molecular and clinical analyses of 84 patients with tuberous sclerosis complex. BMC Med Genet 2006; 7: 72. 
3. Tuberous sclerosis fact sheet. NINDS: 2006-04-11. Retrieved 2007-01-09.

4. Curatolo P, Verdechia M. Neurological Manifestations. In: Curatolo P (Eds). Tuberous sclerosis complex: from basic science to clinical phenotypes. London McKeith Press 2003; pp: 26-45.

5. Cutando A, Gil JA, Lopez T. Oral health management implications in patients with tuberous sclerosis. Oral Surg Oral Med Oral Pathol Oral Radiol Endol 2000; 90; 430-5.

6. Korol UB, Schoor R, Nanda V, Almas K, Phelan JA. Gingival enlargement as a manifestation of tuberous sclerosis: case report and periodontal management. J Periodontol 2008; 79: 759-63.

7. Fahsold R, Rott HD, Lorenz P. A third gene locus for tuberous sclerosis is closely linked to the phenylalanine hydroxylase gene locus. Hum Genet 1991; 88: 85-90.

8. Roach ES, Sparagana SP. Diagnosis of tuberous sclerosis complex. J Child Neurol 2004; 19: 643-9.

9. Ridler K, Suckling J, Higgins NJ, de Vries PJ, Stephenson CM, Bolton PF, Bullmore ET. Neuroanatomical correlates of memory deficits in tuberous sclerosis complex. Cereb Cortex 2007; 17: 261-71.

10. Ridler K, Suckling J, Higgins N, Bolton P, Bullmore E. Standardized whole brain mapping of tubers and subependymal nodules in tuberous sclerosis complex. $\mathrm{J}$ Child Neurol 2004; 19: 658-65.

11. DiMario FJ. Brain abnormalities in tuberous sclerosis complex. J Child Neurol 2004; 19: 650-7.

12. Lie JT. Cardiac, pulmonary, and vascular involvement in tuberous sclerosis. Annals of the New York Academy of Science 1991; 68: 58-70.

13. Cope JT, Lindsey JH, Kron IL. Cardiac tumours. In Mavroudis C, Backer CL. Pediatric cardiac surgery.3rd ed. Philadelphia: Mosby 2003; 3: 689-701.

14. Schwartz RA, Fernandez G, Kotulska K, Jozwick S. Tuberous Sclerosis Complex: advances in diagnosis, genetics, and management. J Am Acad Dermatol 2007; 57: 189-202.

15. Yates JR. Tuberous sclerosis. Eur J Hum Genet 2006; 14: 1065-73.

16. Chiron C, Dulac O, Beaumont D, Palacios L, Pajot N, Mumford J. Therapeutic trial of Vigabatrin in refractory infantile spasms. J Child Neurol 1991; 2: S52-9.

17. Aicardi J, Mumford JP, Dumas C, Wood S. Vigabatrin as initial therapy for infantile spasms: a European retrospective survey. Sabril IS Investigator and Peer Review Groups. Epilepsia 1996; 37: 638-42.

18. Franz DN, Tudor C, Leonard J. Topiramate as initial therapy in tuberous sclerosis complex-associated seizures. Epilepsia 2000; 41: 87.

19. Shepherd C, Gomez M, Lie J, Cronson C. Causes of death in patients with tuberous sclerosis. Mayo Clin Proc 1991; 66: 792-6. 